\title{
Perbandingan Ekstraksi Vitamin C dari 10 Jenis Buah-Buahan Menggunakan Sonikasi dan Homogenisasi
}

\author{
Olha Rantung ${ }^{1}$, Aneke Ireine Korua ${ }^{1}$, Hasan Datau ${ }^{1}$ \\ ${ }^{1}$ Laboratorium Terpadu Universitas Sam Ratulangi, Manado 95115. \\ Corresponding author.E-mail : olharantung@gmail.com \\ Submisi : 25 Oktober 2021 ; Penerimaan: 11 Januari 2022
}

\begin{abstract}
ABSTRAK
Penelitian ini bertujuan untuk menentukan kandungan vitamin $C$ pada 10 jenis buahbuahan pada beberapa $\mathrm{pH}$ menggunakan spektrofotometer UV dan membandingkan metode ekstraksi secara sonikasi dan homogenasi. Penelitian ini terdiri dari 2 tahap yaitu ekstraksi dan uji kandungan vitamin C. Proses ekstraksi dilakukan dengan dua cara yaitu sonikasi dan homogenisasi dengan penambahan beberapa $\mathrm{pH}$ (2-7). Analisis vitamin $\mathrm{C}$ dilakukan dengan metode spektrofotometer UV. Panjang gelombang maksimum vitamin C yang diperoleh adalah $264 \mathrm{~nm}$ dengan absorbansi 0,515, sehingga diperoleh persamaan regresi linier adalah $Y=$ $0,073 x+0,023$. Hasil penelitian menunjukkan bahwa kadar vitamin $C$ tertinggi terdapat pada $\mathrm{pH}$ asam (2-5) dan dari kedua metode ekstraksi yang digunakan pada penelitian ini tertinggi terdapat pada ekstraksi secara sonikasi.
\end{abstract}

Kata kunci: Homogenisasi; Sonikasi; Vitamin C.

\section{PENDAHULUAN}

Salah satu senyawa kompleks yang dibutuhkan oleh tubuh adalah vitamin C. Vitamin C bermanfaat membantu proses metabolisme atau pengaturan tubuh. Pengukuran kandungan vitamin $\mathrm{C}$ dapat dilakukan dengan beberapa metode, diantaranya metode titrasi asam-basa, metode titrasi 2,6 D (dichloroindophenol), metode spektrofotometri, dan metode titrasi iodium (Techinamuti \& Pratiwi, 2018).

Pada makananan yang dikonsumsi jika kekurangan vitamin $\mathrm{C}$ dapat mengakibatkan penurunan daya tahan tubuh. Konsentrasi vitamin per hari yang memenuhi jumlah kecukupan gizi yang berkaitan dengan kesehatan harus disesuaikan dengan Recomended Daily Allowance (RDA) (Yuliarti, 2009). Kebutuhan vitamin $\mathrm{C}$ yang dianjurkan sebesar $30 \mathrm{mg}$ sampai $60 \mathrm{mg}$ per hari (Putri \& Setiawati, 2015).

Selain itu, vitamin C bermanfaat sebagai senyawa yang bisa mengurangi resiko kanker payudara, rektum, paruparu, dan kolon (Al Majidi \& Al Quruby, 2016). Dalam pengujian aktivitas antioksidan biasanya menggunakan vitamin $C$ sebagai pembanding karena vitamin $C$ adalah senyawa antioksidan alami. Selain itu, antioksidan alami tidak menimbulkan toksisitas dan relatif aman. Berdasarkan penelitian, jika dibandingkan dengan vitamin $\mathrm{A}$ dan Vitamin $E$, vitamin $C$ lebih sering digunakan sebagai senyawa pembanding karena lebih mudah diperoleh dan murah (Lung \& Destiani, 2015). Vitamin C juga disebut sebagai donor elektron (pemberi elektron) sehingga termasuk dalam senyawa antioksidan. Sebagai pemberi elektron, vitamin $C$ juga bisa diartikan sebagai agen reduktor, berasal dari sifat ikatan ganda antara C-2 dan C-3 dari cicin lakton 6-karbon tersebut. Vitamin $\mathrm{C}$ bisa mencegah senyawa-senyawa lain mengalami oksidasi. Secara alamiah vitamin $C$ itu sendiri yang mengalami oksidasi (Wijaya, 2014). 
Dalam kehidupan sehari-hari, vitamin $C$ bersumber dari buah buahan seperti nanas, jambu biji, sirsak, jeruk, mangga, dan lain-lain (Yuliarti, 2011). Kandungan vitamin $\mathrm{C}$ dari berbagai buah buahan itu bervariasi, untuk itu perlu adanya metode untuk mengetahui kandungan vitamin $\mathrm{C}$ dari sumber buahbuahan yang ada.

Umumnya, penetapan kadar dapat dilakukan secara analisis menggunakan metode spektrofotometri UV-Vis dan titrasi iodometri (Karinda et al., 2013; Mulyani, 2017). Prinsip kerja metode iodometri ini adalah asam askorbat mempunyai potensial reduksi yang lebih rendah dibandingkan dengan iodium, sehingga iodium akan mengoksidasi senyawa asam askorbat. Pengujian dengan metode ini relative murah dan cukup mudah, namun kurang efektif untuk mengukur kadar asam askorbat, karena dalam bahan pangan terdapat senyawa lain yang juga bersifat pereduksi selain asam askorbat (Karinda et al., 2013). Sedangkan prinsip analisis kerja metode spektrofotometri UV-Vis ini karena vitamin $\mathrm{C}$ memiliki gugus kromofor maka dilakukan dengan mengukur vitamin C secara langsung pada panjang gelombang $265 \mathrm{~nm}$. Berdasarkankan hasil penelitian Karinda et al. (2013), terlihat bahwa hasil metode spektrofotometri UV-Vis lebih besar daripada hasil dengan menggunakan metode iodimetri. Jadi, antara metode iodometri dan metode spektrofotometri UV-Vis terdapat perbedaan yang nyata. kandungan vitamin C pada 10 jenis buah-buahan dengan beberapa larutan $\mathrm{pH}$ menggunakan spektrofotometer UV dan membandingkan metode ekstraksi secara sonikasi dan homogenasi pada penentuan kandungan vitamin $\mathrm{C}$.

Proses ekstraksi dengan gelombang ultrasonik pada frekuensi 42 $\mathrm{kHz}$ sehingga dapat mempercepat waktu kontak antara pelarut dan sampel walaupun pada suhu ruang disebut metode sonikasi. Hal ini menyebabkan proses perpindahan massa antara senyawa bioaktif dari dalam sampel ke pelarut menjadi lebih cepat. Pemanfaatan energi gelombang pada metode sonikasi ini megakibatkan terjadinya proses kavitasi, yakni suatu proses pembentukan gelembunggelembung kecil yang dihasilkan dari adanya transmisi gelombang ultrasonik untuk membantu difusi pelarut ke dalam dinding sel sampel (Ashley et al., 2001).

\section{METODE PENELITIAN}

\section{Bahan dan alat}

10 jenis buah-buahan (anggur, apel, jambu biji, lemon cui, lemon manis, mangga, naga, nanas, salak dan sirsak) yang diperoleh dari Freshmart Superstore bahu Mall Manado, asam askorbat, aquabides (sterile water for irrigation), buffer $\mathrm{HCl}-\mathrm{KCl} \mathrm{pH} \mathrm{2,0}$, buffer Sitrat $\mathrm{pH} 3,0$, buffer Asetat $\mathrm{pH} 4,0$ dan $\mathrm{pH}$ 5,0 , buffer Phosphate $\mathrm{pH}$ 6,0 dan buffer $\mathrm{pH}$ 7.0. Alat-Alat yang digunakan adalah blender (Philips), timbangan analitik (Uni Bloc), sentrifuge (Clements 2000), saringan vakum (Rocker 300), corong, spatula, kertas saring (whatman no 41), labu ukur, gelas ukur, beaker glass, erlenmeyer, batang pengaduk, pipet volume, glasfirn.pi.pump, rak dan tabung reaksi, talenan, pisau, vortex (mixer), sonicator (Ultrasonic Cleaner Power 120 $\mathrm{W}$, Frekuency $40 \mathrm{KHz}$, timer 0-30 min) dan spektrofotometer UV-Vis (Shimadzu 1800).

\section{Preparasi sampel}

Sampel 10 jenis buah-buahan (anggur, apel, biji, lemon cui, lemon manis, mangga, naga, nanas, salak, dan sirsak), daging buah dipotong kecil-kecil, ditimbang sebanyak $200 \mathrm{gr}$ dan dihaluskan menggunakan blender sampai menjadi bubur. Selanjutnya 10 
Vol 4 (3) 2021, 124-133/ Olha Rantung, Aneke Ireine Korua \& Hasan Datau

jenis buah yang sudah menjadi bubur dilakukan analisis.

\section{Ekstraksi menggunakan sonikasi Masing-masing sampel yang sudah menjadi bubur ditimbang sebanyak 5 gr lalu ditambahkan dengan $50 \mathrm{~mL}$ masing-masing larutan $\mathrm{pH} 2,0$ sampai $\mathrm{pH} 7,0$. Kemudian diekstraksi menggunakan sonicator selama 5 menit dengan suhu 34 oC kemudian disentrifus dengan kecepatan $3500 \mathrm{rpm}$ sehingga diperoleh filtrat jernih.}

\section{Ekstraksi secara homogenisasi (mixer)}

Masing-masing sampel yang sudah menjadi bubur ditimbang sebanyak 5 gr lalu ditambahkan dengan $50 \mathrm{~mL}$ masing-masing larutan $\mathrm{pH}$ 2,0 sampai $\mathrm{pH} \quad 7,0 . \quad$ Kemudian dihomogenisasi selama 5 menit, lalu disentrifuse sehingga diperoleh filtrat jernih.

\section{Pembuatan larutan induk vitamin C 100 ppm}

Ditimbang sebanyak $50 \mathrm{mg}$ asam askorbat dimasukkan ke dalam labu ukur $500 \mathrm{~mL}$ yang telah dibungkus dengan aluminium foil dan dilarutkan dengan aquabides sampai tanda tera.

\section{Pembuatan larutan kurva kalibrasi}

Larutan vitamin C 100 ppm dipipet ke dalam labu takar $100 \mathrm{~mL}$ yang telah di bungkus aluminium foil masing-masing 1 , 3, 5, 7, 9 dan $11 \mathrm{~mL}$. kemudian ditambahkan aquabides hingga tanda tera lalu dihomogenkan sehingga didapatkan konsentrasi, 1, 3, 5, 7, 9, dan $11 \mathrm{ppm}$.

\section{Penentuan panjang gelombang maksimum larutan vitamin $\mathrm{C}$}

Dari larutan kurva kalibrasi diambil larutan konsentrasi $7 \mathrm{ppm}$ lalu dimasukkan ke dalam kuvet, kemudian diukur pada panjang gelombang 200-400 $\mathrm{nm}$ dengan aquabides sebagai blanko.
Pengukuran larutan kurva kalibrasi Masing-masing larutan kurva kalibrasi $1,3,5,7,9$, dan $11 \mathrm{ppm}$ diukur absorbansinya pada panjang gelombang maksimum yang diperoleh. Setelah itu dibuat kurva kalibrasi dan dihitung persamaan regresi linier dari data yang diperoleh.

\section{Penentuan kadar vitamin C tiap sampel \\ Masing-masing filtrat buah dari hasil ekstraksi sonikasi dan homogenisasi dipipet sebanyak $0,1 \mathrm{~mL}$ lalu dimasukkan ke dalam labu ukur 10 $\mathrm{mL}$ kemudian ditambahkan dengan 9,9 $\mathrm{mL}$ larutan masing-masing $\mathrm{pH}(\mathbf{p H ~ 2 , 0}$ sampai pH 7,0). Kemudian divorteks lalu dibaca absorbansinya pada panjang gelombang maksimum yang diperoleh daan dilakukan sebanyak 3 kali ulangan untuk tiap sampel.}

\section{Analisis data}

Analisis data dilakukan dengan menggunakan persamaan regresi linier $Y$ $=\mathrm{BX}+\mathrm{A}$ dengan memasukkan nilai absorbansi sampel ke kurva kalibrasi. Persamaan ini digunakan untuk menghitung kadar vitamin $\mathrm{C}$ dalam sampel. Dimana $(X)$ menyatakan kadar vitamin $C$ dalam sampel dan (Y) menyatakan nilai pengukuran absorbansi.

\section{HASIL DAN PEMBAHASAN}

\section{Preparasi dan ekstraksi sampel}

Vitamin C merupakan salah satu jenis vitamin yang ada dalam uahbuahan yang diperlukan oleh tubuh. Vitamin C efektif mengatasi radikal bebas yang merusak jaringan atau sel dan berfungsi sebagai antioksidan (Tayebrezvani et al, 2013). Sampel yang digunakan pada penelitian ini adalah 10 jenis buah-buahan (anggur, apel, jambu biji, lemon cui, lemon manis, mangga, naga, nanas, salak, dan sirsak). Daging 
buah dipotong-potong kecil, ditimbang sebanyak $200 \mathrm{~g}$ dan dihaluskan dengan blender sampai menjadi bubur. Selanjutnya masing-masing sampel (10 jenis buah) yang sudah menjadi bubur lalu diekstraksi dengan dua cara yaitu ekstraksi dengan sonikasi dan homogenisasi dengan penambahan larutan $\mathrm{pH}$ (2-7). Penambahan larutan asam ini $(\mathrm{pH} 2-7)$ bertujuan untuk menstabilkan vitamin $\mathrm{C}$, sejalan dengan yang dilakukan oleh Sutanto \& Rahayuni (2013). Setelah itu disentrifuse sehingga diperoleh filtrat jernih filtrat jernih yang diperoleh berupa filtrat jernih 10 jenis buah yang diekstraksi secara sonikasi dan homogenisasi.

Pelarut yang digunakan pada penelitian ini adalah pelarut aquabides yang steril dikarenakan vitamin $\mathrm{C}$ merupakan vitamin yang bisa larut di air. Tujuan menggunakan pelarut aquabides adalah untuk mengurangi resiko adanya zat pengotor dan bebas dari pirogen. Hal tersebut sejalan dengan yang dilakukan Suhaera et al. (2019) yang menyatakan bahwa aquades adalah pelarut yang digunakan dengan tujuan mengurangi adanya resiko keberadaan suatu pengokor serta vitamin C merupakan vitamin yang larut dalam air.

\section{Larutan induk vitamin C}

Pembuatan larutan induk vitamin C menggunakan larutan standar asam askorbat yang dibuat dengan konsentrasi 100 ppm, dimana sebanyak $50 \mathrm{mg}$ asam askorbat yang dimasukkan pada labu takar $500 \mathrm{~mL}$ yang telah dibungkus dengan aluminium foil dan dilarutkan dengan aquabides sampai tanda tera sehingga diperoleh larutan induk vitamin C $100 \mathrm{ppm}$. Selanjutnya pembuatan larutan kurva kalibrasi, dimana larutan induk vitamin C 100 ppm yang diperoleh dipipet ke dalam labu ukur $100 \mathrm{~mL}$ yang telah dibungkus aluminium foil masingmasing $1,3,5,7,9$, dan $11 \mathrm{~mL}$, Ialu ditambahkan aquabides sampai tanda tera dan dihomogenkan sehingga diperoleh larutan standar dengan konsentrasi 1, 3 , 5 , 7, 9 dan $11 \mathrm{ppm}$.

\section{Panjang gelombang maksimum larutan vitamin $\mathbf{C}$}

Tabel 1. Pengukuran absorbansi asam askorbat 7 ppm

\begin{tabular}{cc}
\hline Panjang gelombang $(\mathrm{nm})$ & Absorbansi \\
\hline 200 & 0,080 \\
204 & 0,055 \\
208 & 0,044 \\
212 & 0,045 \\
216 & 0,055 \\
220 & 0,073 \\
224 & 0,098 \\
228 & 0,130 \\
232 & 0,169 \\
236 & 0,213 \\
240 & 0,259 \\
244 & 0,308 \\
248 & 0,361 \\
252 & 0,416 \\
256 & 0,467 \\
260 & 0,502 \\
264 & 0,515 \\
268 & 0,498 \\
272 & 0,447 \\
276 & 0,370 \\
280 & 0,279 \\
284 & 0,193 \\
288 & 0,123 \\
292 & 0,071 \\
296 & 0,035 \\
300 & 0,014 \\
\hline
\end{tabular}

Penentuan panjang gelombang maksimum vitamin $\mathrm{C}$ dilakukan karena panjang gelombang suatu molekul atau senyawa bisa berbeda-beda jika ditentukan dengan alat yang berbeda dan kondisi yang berbeda. Keadaan eksitasi elektronik yang memberikan absorbansi maksimum disebut sebagai panjang gelombang maksimum. Adapun tujuan dari menentukan panjang gelombang maksimum adalah untuk mengukur perubahan absorbansi yang terjadi untuk setiap satuan konsentrasi yang paling besar untuk mendapatkan panjang gelombang yang mana kepekaan analisis yang maksimum bisa diperoleh (Gandjar \& Rohman, 2007). Penentuan panjang gelombang 
maksimum dilakukan dengan mengukur nilai absorbansi larutan asam askorbat pada salah satu larutan standar yaitu 7 ppm pada rentang panjang gelombang $200 \mathrm{~nm}$ sampai $300 \mathrm{~nm}$ dengan menggunakan spektrofotometer UV-Vis. Hasil pengukuran absorbansi asam askorbat $7 \mathrm{ppm}$ disajikan pada Tabel 1 dan spektra absorbansi asam askorbat dengan konsentrasi 7 ppm disajikan pada Gambar 1.
Berdasarkan Tabel 1 dan Gambar 1, menunjukkan bahwa hasil yang diperoleh berdasarkan pengukuran dari spektrofotometri UV-Vis, diperoleh panjang gelombang maksimum pada larutan standar yang digunakan yaitu asam askorbat pada $7 \mathrm{ppm}$ dengan nilai absorbansi sebesar 0,515 dan panjang gelombang $264 \mathrm{~nm}$.

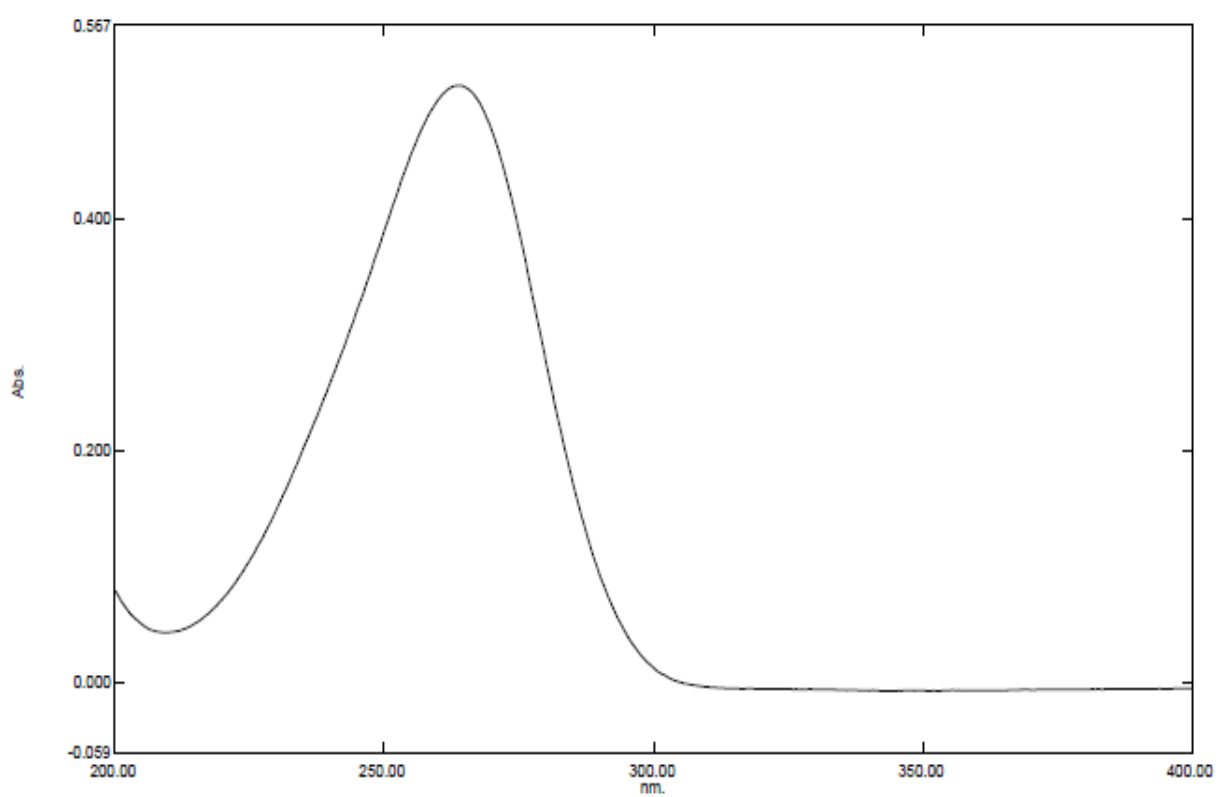

Gambar 1. Spektra asam askorbat 7 ppm

\section{Kurva kalibrasi vitamin C}

Untuk mengetahui daerah rentang linearitas larutan standar vitamin C dilakukan pembuatan kurva kalibrasi vitamin C. Hal ini dilakukan dengan meggunakan absorbansi yang diperoleh dari hasil pengukuran dengan menggunakan variasi konsentrasi yang dibuat. Dari larutan induk 100 ppm dibuat dengan sederetan konsentrasi, diantaranya $0,1,3,5,7,9$, dan $11 \mathrm{ppm}$ dan diukur absorbansinya menggunakan spektrofotometer UV-Vis dengan panjang gelombang maksimum yang diperoleh yaitu $264 \mathrm{~nm}$ sehingga diperoleh hasil pengukuran absorbansi asam askorbat dengan beberapa konsentrasi pada panjang gelombang $264 \mathrm{~nm}$ yang dapat disajikan pada Tabel 2. Selanjutnya absorbansi yang didapatkan dibuat sebagai standar yang berbentuk kurva yang disajikan pada Gambar 2.

Tabel 2. Absorbansi asam askorbat pada panjang gelombang $264 \mathrm{~nm}$

\begin{tabular}{ll}
\hline Konsentrasi (ppm) & Absorbansi \\
\hline 0 & 0,001 \\
1 & 0,094 \\
3 & 0,260 \\
5 & 0,405 \\
7 & 0,547 \\
9 & 0,680 \\
11 & 0,810 \\
\hline
\end{tabular}


Berdasarkan kurva kalibrasi asam askorbat yang didapatkan bahwa peningkatan larutan standar vitamin C mempengaruhi meningkatnya nilai absorbansi yang dapat terukur. Yang berarti, semakin besar absorbansi yang dihasilkan maka semakin besar juga konsentrasi larutan standar vitamin C yang digunakan. Hal ini sejalan dengan yang dilakukan Fadliya et al. (2018) menyatakan peningkatan nilai absorbansi yang terbaca menggunakan instrumen spektrofotometri UV-vis secara linier dipengaruhi oleh peningkatan konsentrasi vitamin $\mathrm{C}$. Hal tersebut sesuai dengan prinsip hukum Lambert-Beer yang menyatakan bahwa nilai absorbansi berbanding lurus dengan konsentrasi suatu sampel.

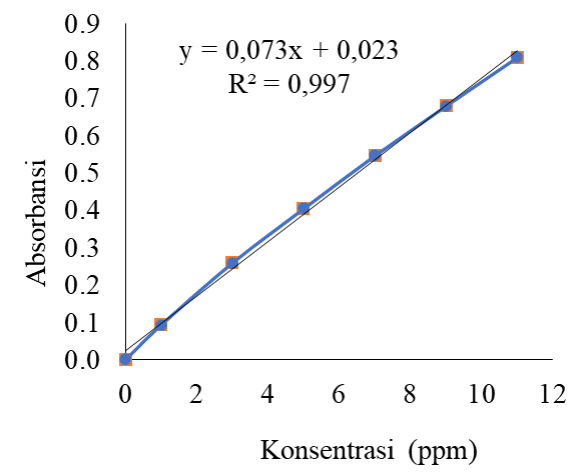

Gambar 2. Kurva kalibrasi asam askorbat

Berdasarkan data nilai absorbansi larutan standar yang didapatkan, maka diperoleh persamaan $Y=0,073 x+0,023$ dengan nilai koefisien korelasi ( $r$ ) sebesar 0,997 yang menunjukkan kurva linearitas dari persamaan tersebut. Yang mana jika nilai $r=+$ (positif), maka hubungan absorbansi dan konsentrasi berbanding lurus, artinya nilai $r$ yang didapat sudah sesuai dengan prinsip hukum Lambert-Beer (Primadiamanti et al., 2019). Hal ini sejalan dengan penelitian yang dilakukan oleh Chandra et al. (2019) yang menyatakan koefisien korelasi ini menunjukkan hasil linear, karena memenuhi persyaratan dimana nilai $(r)$ berada pada rentang $0,9 \leq r \leq 1$. Maka kurva kalibrasi ini sudah cukup baik, dan persamaan garis regresi dapat digunakan untuk perhitungan kandungan vitamin $C$ di dalam sampel.

\section{Konsentrasi vitamin $\mathrm{C}$ menggunakan ekstraksi sonikasi dan homogenisasi} Analisis vitamin C pada sampel (10 jenis buah) ditentukan menggunakan spektrofotometer UV-Vis. Alat yang digunakan untuk mengukur reflektansi, absorbansi, dan transmitansi dari cuplikan sebagai fungsi dari panjang gelombang adalah Spektrofotometer UV. Cara menentukan konsentrasi vitamin $\mathrm{C}$ yaitu dipipet sebanyak $0,1 \mathrm{~mL}$ masingmasing filtrat buah dari hasil ekstraksi sonikasi dan homogenasi ke dalam labu ukur $10 \mathrm{~mL}$ dan ditambahkan dengan 9,9 $\mathrm{mL}$ larutan $\mathrm{pH}(\mathrm{pH} 2,0$ sampai $\mathrm{pH} 7,0)$ pada masing-masing filtrat. Selanjutnya divorteks dan absorbansinya dibaca pada panjang gelombang maksimum yang diperoleh yaitu $264 \mathrm{~nm}$. Sehingga diperoleh konsentrasi vitamin $\mathrm{C}$ dari 10 jenis buah dengan beberapa larutan $\mathrm{pH}$ yang diekstraksi secara sonikasi yang terdapat pada Tabel 3 dan diekstraksi secara homogenisasi yang terdapat pada Tabel 4.

Berdasarkan Tabel 3 dan 4 , menunjukkan bahwa konsentrasi vitamin C dari 10 jenis buah yang diekstraksi secara sonikasi dan homogenisasi yang tertinggi terdapat pada $\mathrm{pH}$ asam secara berurutan adalah $\mathrm{pH} 2, \mathrm{pH} \mathrm{5,} \mathrm{pH} 4$ dan $\mathrm{pH}$ 3. Ini dikarenakan asam askorbat lebih stabil pada $\mathrm{pH}$ asam. Hal ini sesuai dengan pendapat Winarno (2013) yang menyatakan bahwa vitamin $\mathrm{C}$ atau asam askorbat memiliki sifat stabil dalam suasana asam. Selain itu, penelitian yang dilakukan Ratuca \& Arintina (2013), juga menyatakan bahwa asam askorbat atau vitamin $C$ bersifat mudah rusak oleh panas, oksidasi, dan alkali dan mudah larut dalam air namun stabil pada $\mathrm{pH}$ 
Vol 4 (3) 2021, 124-133/ Olha Rantung, Aneke Ireine Korua \& Hasan Datau

asam. Sedangkan pada $\mathrm{pH} 6$ dan $\mathrm{pH} 7$ menunjukkan konsentrasi vitamin $\mathrm{C}$ mengalami penurunan, ini diduga bahwa konsentrasi vitamin $\mathrm{C}$ akan menurun pada $\mathrm{pH}$ netral. Hal ini sejalan dengan penelitian yang dilakukan Herbig \&
Renard (2017) yang menyatakan bahwa kestabilan asam askorbat akan menurun pada $\mathrm{pH}$ mendekati netral dikarenakan asam askorbat akan mengalami degradasi lebih cepat dibandingkan $\mathrm{pH}$ asam (2-5).

Tabel 3. Pengaruh $\mathrm{pH}$ terhadap konsentrasi vitamin $\mathrm{C}$ dari 10 jenis buah yang diekstraksi secara sonikasi

\begin{tabular}{|c|c|c|c|c|c|c|}
\hline sampel & $\mathrm{pH} 2$ & $\mathrm{pH} 3$ & $\mathrm{pH} 4$ & $\mathrm{pH} 5$ & $\mathrm{pH} 6$ & $\mathrm{pH} 7$ \\
\hline Anggur & $9,44 \pm 0,17$ & $1,70 \pm 0,05$ & $10,45 \pm 0,10$ & $7,74 \pm 0,09$ & $1,50 \pm 0,06$ & $1,59 \pm 0,07$ \\
\hline Apel & $9,20 \pm 0,02$ & $1,48 \pm 0,02$ & $10,53 \pm 0,11$ & $7,79 \pm 0,11$ & $1,55 \pm 0,09$ & $1,64 \pm 0,06$ \\
\hline Jambu biji & $11,05 \pm 0,49$ & $3,42 \pm 0,14$ & $13,33 \pm 0,02$ & $11,67 \pm 0,06$ & $5,64 \pm 0,19$ & $5,47 \pm 0,07$ \\
\hline Lemon cui & $13,48 \pm 0,11$ & $6,07 \pm 0,37$ & $14,06 \pm 0,42$ & $12,64 \pm 0,17$ & $6,65 \pm 0,30$ & $6,58 \pm 0,22$ \\
\hline $\begin{array}{l}\text { Lemon } \\
\text { manis }\end{array}$ & $10,02 \pm 0,06$ & $7,72 \pm 0,07$ & $9,32 \pm 0,21$ & $9,08 \pm 0,29$ & $1,58 \pm 0,03$ & $1,48 \pm 0,04$ \\
\hline Mangga & $10,05 \pm 0,10$ & $4,77 \pm 0,03$ & $10,24 \pm 0,11$ & $10,42 \pm 0,09$ & $2,48 \pm 0,06$ & $2,60 \pm 0,09$ \\
\hline Naga & $9,19 \pm 0,12$ & $7,13 \pm 0,03$ & $0,83 \pm 0,02$ & $7,69 \pm 0,12$ & $1,08 \pm 0,06$ & $1,04 \pm 0,04$ \\
\hline Nanas & $9,26 \pm 0,10$ & $6,88 \pm 0,01$ & $9,51 \pm 0,14$ & $7,35 \pm 0,16$ & $1,06 \pm 0,02$ & $1,15 \pm 0,04$ \\
\hline Salak & $8,79 \pm 0,19$ & $2,67 \pm 0,10$ & $1,80 \pm 0,03$ & $7,76 \pm 0,28$ & $1,91 \pm 0,13$ & $2,04 \pm 0,12$ \\
\hline Sirsak & $10,49 \pm 0,15$ & $3,36 \pm 0,07$ & $11,81 \pm 0,06$ & $9,77 \pm 0,06$ & $3,35 \pm 0,10$ & $2,24 \pm 0,09$ \\
\hline
\end{tabular}

Tabel 4. Pengaruh $\mathrm{pH}$ terhadap konsentrasi vitamin $\mathrm{C}$ dari 10 jenis buah yang diekstraksi secara homogenisasi.

\begin{tabular}{lllllll}
\hline sampel & $\mathrm{pH} 2$ & $\mathrm{pH} 3$ & $\mathrm{pH} 4$ & $\mathrm{pH} 5$ & $\mathrm{pH} 6$ & $\mathrm{pH} 7$ \\
\hline Anggur & $9,34 \pm 0,07$ & $1,39 \pm 0,04$ & $10,50 \pm 0,05$ & $8,17 \pm 0,09$ & $1,90 \pm 0,04$ & $2,01 \pm 0,05$ \\
Apel & $8,78 \pm 0,09$ & $1,50 \pm 0,08$ & $10,31 \pm 0,05$ & $7,79 \pm 0,15$ & $1,37 \pm 0,06$ & $1,41 \pm 0,01$ \\
Jambu biji & $11,82 \pm 0,12$ & $2,96 \pm 0,14$ & $12,29 \pm 0,05$ & $10,31 \pm 0,21$ & $4,77 \pm 0,03$ & $4,62 \pm 0,53$ \\
Lemon cui & $12,12 \pm 0,76$ & $7,50 \pm 0,58$ & $6,85 \pm 0,11$ & $12,26 \pm 0,34$ & $6,89 \pm 0,12$ & $7,01 \pm 0,15$ \\
Lemon & $8,97 \pm 0,17$ & $6,92 \pm 0,06$ & $8,67 \pm 0,14$ & $7,85 \pm 0,24$ & $1,15 \pm 0,09$ & $0,91 \pm 0,05$ \\
manis & $10,23 \pm 0,18$ & $5,34 \pm 0,17$ & $11,14 \pm 0,06$ & $9,07 \pm 0,03$ & $1,50 \pm 0,11$ & $1,83 \pm 0,21$ \\
Mangga & $8,24 \pm 0,09$ & $6,26 \pm 0,24$ & $0,89 \pm 0,01$ & $7,42 \pm 0,06$ & $0,35 \pm 0,04$ & $0,19 \pm 0,05$ \\
Naga & $9,16 \pm 0,06$ & $6,90 \pm 0,16$ & $9,52 \pm 0,12$ & $7,39 \pm 0,11$ & $1,22 \pm 0,08$ & $1,37 \pm 0,01$ \\
Nanas & $8,89 \pm 0,09$ & $1,14 \pm 0,04$ & $0,93 \pm 0,01$ & $7,17 \pm 0,15$ & $0,84 \pm 0,01$ & $1,19 \pm 0,04$ \\
Salak & $9,84 \pm 0,38$ & $3,02 \pm 0,02$ & $11,99 \pm 0,12$ & $9,87 \pm 0,14$ & $3,51 \pm 0,15$ & $3,71 \pm 0,04$ \\
Sirsak & & & & & &
\end{tabular}

\section{Pengaruh metode ekstraksi terhadap kandungan vitamin $\mathrm{C}$}

Dalam penelitian ini menggunakan dua jenis ekstraksi yang berbeda yakni sonikasi dan homogenisasi. Ekstraksi Ultrasonic-assisted extraction (UAE) adalah salah satu metode ekstraksi yang menggunakan ultrasonik. UAE adalah metode ekstraksi dengan prinsip kerja yang menggunakan gelombang ultrasonik yang menyebabkan pecahnya dinding sel tanaman sehingga isi sel terlepas ke media ekstraksi (Toma et al., 2001). Sedangkan ekstraksi yang memanfaatkan penyeragaman ukur partikel sehingga terlarut secara sempurna dengan mempertahankan kestabilan dari sebuah campuran disebut 
sebagai ekstraksi homogenisasi. Proses pengecilan ukuran pada fase terdispersi dilakukan untuk tujuan penyeragaman ukuran partikel. Hasil perbandingan kandungan vitamin $\mathrm{C}$ menggunakan ekstraksi secara sonikasi dan homogenisasi dari beberapa larutan $\mathrm{pH}$ dapat disajikan pada Gambar 3.

Huruf yang berbeda pada warna yang berbeda menunjukkan hasil yang beda nyata secara statistik. Berdasarkan Gambar 3. Dapat disimpulkan bahwa kandungan vitamin $\mathrm{C}$ yang diekstraksi secara sonikasi dan homogenisasi dengan beberapa larutan $\mathrm{pH}$ yang tertinggi diperoleh pada ekstraksi secara sonikasi. Hal ini diduga pada saat sampel diekstraksi secara sonikasi kandungan vitamin $\mathrm{C}$ yang terdapat pada sampel akan lebih mudah terekstrak. Hal ini didukung penelitian Pradana et al. (2017), yang menyatakan bahwa Efek kavitasi yang dihasilkan oleh gelombang ultrasonik dapat memutus sel tumbuhan untuk memudahkan penetrasi pelarut ke dalam sel. Sehingga dari data yang diperoleh menunjukkan bahwa ekstraksi secara sonikasi untuk mengetahui kandungan vitamin $\mathrm{C}$ pada buah-buahan dapat dijadikan sebagai alternatif baru dalam proses esktraksi.

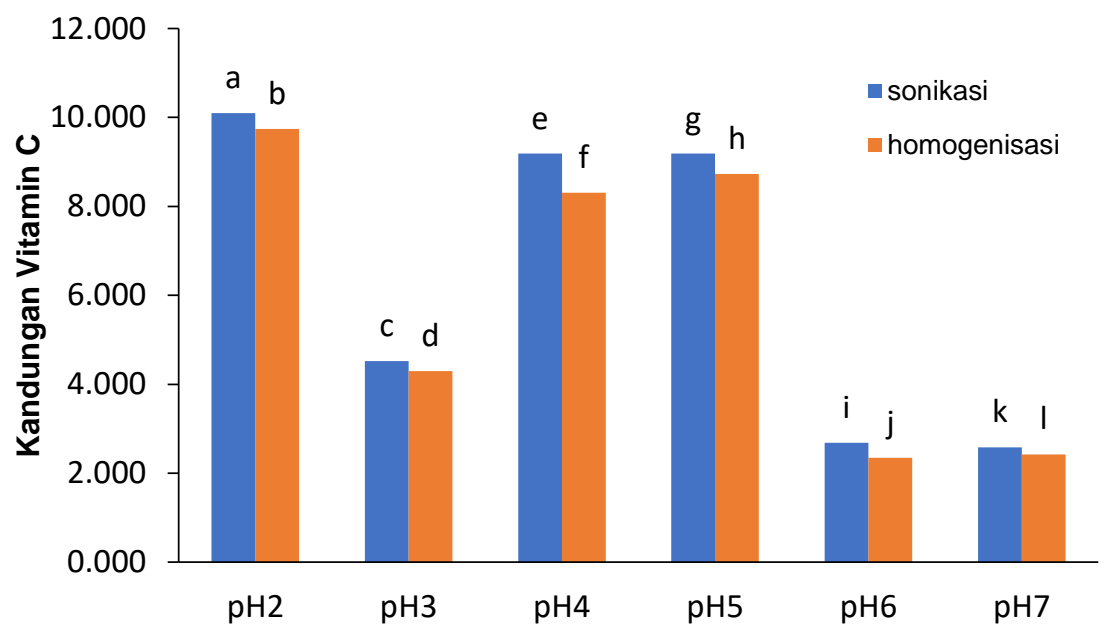

Gambar 3. Diagram perbandingan kandungan vitamin $\mathrm{C}$ menggunakan ekstraksi secara sonikasi dan homogenisasi dari beberapa larutan $\mathrm{pH}$

\section{KESIMPULAN}

Berdasarkan hasil penelitian dapat disimpulkan bahwa kandungan vitamin $\mathrm{C}$ dari 10 jenis buah yang ekstraksi secara sonification tertinggi pada buah lemon cui dengan konsentrasi 14,06 sedangkan secara homogenisasi tertinggi pada buah jambu biji dengan konsentrasi 12,29 dan dari kedua metode ekstraksi yang digunakan pada penelitian ini yang tertinggi terdapat pada ekstraksi secara sonification dibandingkan ekstraksi secara homogenisasi.

\section{DAFTAR PUSTAKA}

Al Majidi, M.I.H. \& Al Quruby, H.Y. 2016. Determination of Vitamin C (ascorbic acid) Contents in Various Fruit and Vegetable by UV Spectrophotometry and Titration Methods. Journal of Chemical and Pharmaceutical Sciences. 9:29722974.

Ashley, K., R.N. Andreas, L. Cavazosa, M. Demage. 2001. Ultrasonic extraction as a sample preparation technique for elemental analysis by atomic spectrometry. Journal of 
Analysis Atomatic Spectrometry. 16: 1447-1153

Chandra, B., Zulharmita, Z. \& Putri, W. D. 2019. Penetapan Kadar Vitamin C Dan B1 Pada Buah Naga Merah (Hylocereus Lemairel (Hook.) Britton \& Rose) Dengan Metode Spektrofotometri UV-Vis. Jurnal Farmasi Higea. 11:62-74.

Fadliya, F., Supriadi, S. \& Diah, A. W. M. 2018. Analisis Vitamin C dan Protein pada Biji Buah Labu Siam (Sechium edule). Jurnal Akademika Kimia. 7:6-10.

Gandjar, G.H. \& Rohman, A. 2007. Kimia Farmasi Analisis. Yogyakarta: Pustaka Pelajar.

Herbig, A.L. \& Renard C.M.G.C. 2017. Factors that Impact the Stability of Vitamin $\mathrm{C}$ at Intermediate Temperatures in a Food Matrix. Food Chemistry. 220:444-451.

Karinda, M., Fatimawali. \& Citraningtyas, G. 2013. Perbandingan Hasil Penetapan Kadar Vitamin C Mangga Dodol Dengan Menggunakan Metode Spektrofotometri UV-Vis Dan Iodometri. Jurnal IImiah Farmasi. 12:86-89.

Lung, J.K.S. \& Destiani, D.P. 2015. Uji Aktivitas Antioksidan Vitamin A, C, $\mathrm{E}$ dengan metode DPPH. Farmaka. 15:53-62.

Mulyani, E. 2017. Perbandingan Hasil Penetapan Kadar Vitamin C pada Buah Kiwi (Actinidia deliciousa) dengan Menggunakan Metode lodimetri dan Spektrofotometri UVVis. Pharmauko Jurnal Farmasi, Sains, dan Kesehatan. 3: 14-17.

Pradana, P.F., Khoirul, M.D.D. \& Septian, E.A. 2017. The Effectiveness Test of Ultrasonic Extraction Microwave Distilation Method in Capsaicin Extraction. Journal of Engineering. 3:6-10.

Primadiamanti, A., Feladita, N. \& Juliana, R. 2019. Penetapan Kadar Hidrokuinon Pada Krim Pemutih Herbal Yang Dijual Dilorong King Pasar Tengah Kota Bandar Lampung Menggunakan Metode Spektrofotometri UV-Vis. Jurnal Analis Farmasi. 4:10-16.
Putri, M.P. \& Setiawati, Y.H. 2015. Analisis Kadar Vitamin C Pada Buah Nanas Segar (Ananas comosus (L.) Merr) dan Buah Nanas Kaleng Dengan Metode Spektofotometri UV-VIS. Jurnal Wiyata. 2(1):34-38.

Ratuca, S.S. \& Arintina, R. 2013. Pengaruh Pemberian Ph Substrat Terhadap Kadar Serat, Vitamin C dan Tingkat Penerimaan NATA DE CASHEW (Anacardium Occidentale L.). Journal of Nutrition College. 2:200-206.

Suhaera, S., Sammulia, S.F. \& Islamiah, H. 2019. Analisis Kadar Vitamin C pada Buah Naga Merah (Hylocereus lemairei (Hook.) Britton \& Rose) dan Buah Naga Putih (Hylocereus undatus (Haw.) Britton \& Rose) di kepulauan Riau menggunakan Spektrofotometri Ultraviolet. PHARMACY: Jurnal Farmasi Indonesia (Pharmacautical Journal of Indonesia). 16(1):146-152.

Sutanto, R.S. \& Rahayuni, A. 2013. Pengaruh Pemberian $\mathrm{pH}$ Substrat Terhadap Kadar Serat, Vitamin C, Dan Tingkat Penerimaan Nata De Cashew (Anacardium Occidentale L.). Journal of Nutrition College. 2(1):200-206.

Tayebrezvani, H.P., Moradi, F. \& Soltani. 2013. The Effect Of Nitrogen Fixation And Phosphorus Solvent Bacteria On Growth Physiology And Vitamin C Content Of Capsicun Annum L. Iranian Journal Of Plant Physiology. 3:3035.

Techinamuti, N. \& Pratiwi, R. 2018. Metode Analisis Kadar Vitamin C Farmaka. 16(2):309-315.

Toma, M., Vinatoru, M., Paniwnyk, L. \& Mason, T.J. 2001. Investigaton of the Effect of Ultrasound on Vegetal Tissue During Solvent Extraction. Journal Ultrasonic Sonochemistry. 8:137-142.

Wijaya, I.P.B. 2014. Kinetika Perubahan Konsentrasi Asam Askorbat (Vitamin C) Pada Buah Mangga Podang Selama Penyimpanan. Jurnal Online Universitas Kadiri. 
Vol 4 (3) 2021, 124-133/ Olha Rantung, Aneke Ireine Korua \& Hasan Datau

Winarno, F.G. 2013. Kimia Pangan dan Gizi. Jakarta: PT. Garamedia.

Yuliarti, N. 2009. A To Z Food Supplement. Andi: Yogyakarta.

Yuliarti, N. 2011.1001 Khasiat Buah Buahan. CV Andi Offset: Yogyakarta. 